\title{
Dental Implant Placement in Patients on Bisphosphonate Therapy: a Systematic Review
}

\author{
Rokas Gelazius $^{1}$, Lukas Poskevicius ${ }^{1}$, Dalius Sakavicius ${ }^{1}$, Vaidas Grimuta ${ }^{1}$, Gintaras Juodzbalys ${ }^{1}$ \\ ${ }^{1}$ Department of Maxillofacial Surgery, Lithuanian University of Health Sciences, Kaunas, Lithuania.
}

\author{
Corresponding Author: \\ Rokas Gelazius \\ Luksos-Daumanto 2, 206, Kaunas, LT-44001, Kaunas \\ Lithuania \\ Phone: +37067330394 \\ E-mail: gel.rokas@gmail.com
}

\begin{abstract}
Objectives: The review aims to study dental implant placement purposefulness for patients who have been treated or are on treatment with bisphosphonate medication.

Material and Methods: Structured search strategy was applied on electronic databases: MEDLINE, PubMed, PubMed Central and ResearchGate. Scientific publications in English between 2006 and 2017 were identified in accordance with inclusion, exclusion criteria. Publication screening, data extraction, and quality assessment were performed. Outcome measures included implant failure or implant-related osteonecrosis of the jaw.

Results: In total, 32 literature sources were reviewed, and 9 of the most relevant articles that are suitable to the criteria were selected. Heterogeneity between the studies was found and no meta-analysis could be done. Five studies analysed intraoral bisphosphonate medication in relation with implant placement, three studies investigated intravenous bisphosphonate medication in relation with implant placement and one study evaluated both types of medication given in relation with implant placement. Patients with intraoral therapy appeared to have a better implant survival (5 implants failed out of 423) rate at $98.8 \%$ vs. patients treated intravenously (6 implants failed out of 68 ) at 91\%; the control group compared with intraoral bisphosphonate group appeared with $97 \%$ success implant survival rate (27 implants failed out of 842), showing no significant difference in terms of success in implant placement.

Conclusions: Patients treated with intravenous bisphosphonates seemed to have a higher chance of developing implantrelated osteonecrosis of the jaw. The intraorally treated patient group appeared to have more successful results. Implant placement in patients treated intraorally could be considered safe with precautions.
\end{abstract}

Keywords: bisphosphonate-associated osteonecrosis of the jaw; bisphosphonate osteonecrosis; dental implants; oral surgery.

Accepted for publication: 26 September 2018

To cite this article:

Gelazius R, Poskevicius L, Sakavicius D, Grimuta V, Juodzbalys G.

Dental Implant Placement in Patients on Bisphosphonate Therapy: a Systematic Review

J Oral Maxillofac Res 2018;9(3):e2

URL: http://www.ejomr.org/JOMR/archives/2018/3/e2/v9n3e2.pdf

doi: $10.5037 /$ jomr.2018.9302 


\section{INTRODUCTION}

Bisphosphonates (BPs) are widely used medications mainly for the treatment and management of skeletal and oncological diseases such as breast, lung and prostate cancers, multiple myeloma, hypercalcemia, osteoporosis and Paget's disease. According to IMS Health [1], in 2006 around 190 million units of intraoral BPs (mostly used for treatment osteoporosis and osteopenia) were utilized world-wide not to mention usage of intravenous BPs (to treat malignant skeletal oncological diseases) thus referring to Wysowski et al. [2] Approximately 14,7 million intraoral BP prescriptions were dispensed in the US alone in 2012. Although, BPs greatly increase the quality of life for patients, there is a chance that BP-related osteonecrosis (BRONJ) of the jaw may occur (Table 1). Risk factors enhancing BRONJ are periodontal surgery, implant placement, tooth extractions, poor condition of dental prosthesis or chronic mechanical trauma of the jaw bone. Moreover, systemic diseases, consumption of other medications, smoking and alcohol consumption have had a great influence on BP-related osteonecrosis. The occasions of BRONJ have demographic correlations as well for the Caucasian race [3]. Most of the patients treated with bisphosphonates, due to their age, have partial or full edentulism, the need for functional and aesthetic oral rehabilitation by means of dental implantation, which is common in this group of patients [4]. Therefore, the aim of this article is to investigate studies targeted at bisphosphonates effects on dental implant placementprocedure.

\section{MATERIAL AND METHODS Protocol and registration}

Methodology of this article was documented and registered in advance. "Prospero" register no.: CRD42018082609. Protocol can be assessed at: https://www.crd.york.ac.uk/prospero/

The reporting of this systematic analysis adhered to the PRISMA (Preferred Reporting Item for Systematic Review and Meta-Analyses) Statement [5].

\section{Focus question}

The focus question was developed according to the population, intervention, comparison, and outcome (PICO) design (Table 2).

Table 1. Staging and treatment of BRONJ according to reviewed studies ${ }^{\mathrm{a}}$

\begin{tabular}{c|l}
\hline Risk category & No clinical/radiological evidence of exposed bone or infection/inflammation. \\
\hline Treatment plan & $\begin{array}{l}\text { No surgical treatment is needed. Patient has to be informed about following risks. Good oral hygiene with re- } \\
\text { examinations at least once every } 6 \text { months should be done. }\end{array}$ \\
\hline Stage I & $\begin{array}{l}\text { Clinical evidence of exposed bone for more than 8 weeks. This stage is usually asymptomatic. No signs infection is } \\
\text { normally seen. }\end{array}$ \\
\hline Treatment plan & $\begin{array}{l}\text { No surgical treatment is needed. Antibacterial mouth rinses, professional oral hygiene with no injury of exposed } \\
\text { bone can be considered, common follow ups for exposed bone re-evaluation. Antibiotic treatment can be prescribed } \\
\text { if patients condition is difficult. }\end{array}$ \\
\hline Stage II & Exposed/ necrotic bone with signs of infection, drainage of inflammatory matter can appear. \\
\hline Treatment plan & $\begin{array}{l}\text { Management of pain, broad-spectrum antibiotics, antibacterial mouthrinses, debridement of necrotic bone surface } \\
\text { area, common follow ups with professional oral hygiene and re-evaluation of necrotic bone. Drug holidays may be } \\
\text { considered as an option. }\end{array}$ \\
\hline Stage III & Exposed/ necrotic bone with sings of infection. Extraoral fistula, pathological fractures can appear. \\
\hline Treatment plan & $\begin{array}{l}\text { Antibacterial mouthrinses and broad spectrum antibiotics with pain management to prepare patient for surgical } \\
\text { intervention-resection of necrotic bone. Drug holidays may be considered as an option. }\end{array}$ \\
\hline
\end{tabular}

a Stages applies for patients, who used or are using intraoral/intravenous bisphosphonates, and had no history of radiotherapy of head/neck.

Table 2. The focus question development according to the PICOS study design

\begin{tabular}{l|l}
\multicolumn{1}{c|}{ Component } & \multicolumn{1}{c}{ Description } \\
\hline Problem (P) & Osteonecrosis of the jaw. \\
\hline Intervention (I) & Dental implant placement on patients with bisphosphonate therapy. \\
\hline Comparison (C) & Comparison between patients with intraoral and intravenous bisphosphonate therapy. \\
\hline Outcome (O) & Bisphosphonate related osteonecrosis of the jaw. \\
\hline Study design (S) & Randomized controlled trial. \\
\hline Focus question & Is dental implant placement purposeful for patients using bisphosphonates? \\
\hline
\end{tabular}




\section{Types of publications}

The review included studies, case reports, clinical trials on human subjects that were published in English between 2006 and 2017. Letters, editorials, literature reviews, $\mathrm{PhD}$ theses, and abstracts were excluded.

\section{Types of studies}

The review included in vivo (human trials), prospective and retrospective studies published from May $1^{\text {st }}, 2006$, to December $1^{\text {st }}, 2017$, that reported on patient's oral rehabilitation with dental implants using BP medication.

\section{Information sources}

A search was conducted on the "MEDLINE, PubMed, PubMed Central and ResearchGate databases.

\section{Literature search strategy}

According to the PRISMA guidelines, an electronic search was conducted using the MEDLINE, PubMed, PubMed Central and ResearchGate databases to locate articles concerning implant placement in patients using BPs. The keywords that were used during the primary stage were as follows: (((Bisphosphonates) OR BP related osteonecrosis of the jaw) OR (BP osteonecrosis) OR dental implant).

\section{Selection of studies}

The resulting articles were independently subjected to clear inclusion and exclusion criteria by two reviewers as follows. The reviewers compared decisions and resolved differences through discussion, consulting a third party when consensus could not be reached. The third party was an experienced senior reviewer. Full reports were studied of the articles that were deemed eligible for inclusion in this paper (Figure 1).

\section{Population}

Patients presented in the included studies must have been currently using or had used BPs in relation to oral rehabilitation with screw-shaped dental implants with at least a 1-year follow-up after a surgical implant placement operation.

\section{Inclusion criteria}

The applied inclusion criteria for the studies were as follows:

- Studies written in English.

- Patient had to be treated with at least one dental implant before or during oral or intravenous BP therapy.

- Clinical reports with at least a 12-month followup.

- Studies regarding information on BP therapy complications (osteonecrosis of the jaw) and dental implant treatment outcome (survival rate).

\section{Exclusion criteria}

Exclusion criteria for study selection were as follows:

- Previous radiotherapy of head and/or neck area had been done.

- Malignant pathologies or active inflammations were examined at time of implantation.

- Studies of adolescents (under 18 years of age) and elderly people (older than 80).

- In vitro and animal studies.

- Systematic reviews.

\section{Sequential search strategy}

Following the initial literature search, all articles were screened and excluded based on titles and abstracts. The final stage of screening involved reading the full texts to confirm each study's eligibility, based on the inclusion and exclusion criteria.

\section{Data extraction}

The data were independently extracted from studies in the form of variables, according to the aims and themes of the present review, as listed onwards.

\section{Data items}

Data were collected from the included articles and arranged in the following fields:

- "Type of drug" - intraoral or intravenous BP medication.

- "Reason of medication" - motive why BPs are used.

- "Mean age of medication use" - medium time interval of medication used among the patients.

- "Implants in control group" - number of implants placed in patients with no history of BP therapy.

- "Implants in study group" - number of implants placed in patients during or after BP therapy. 


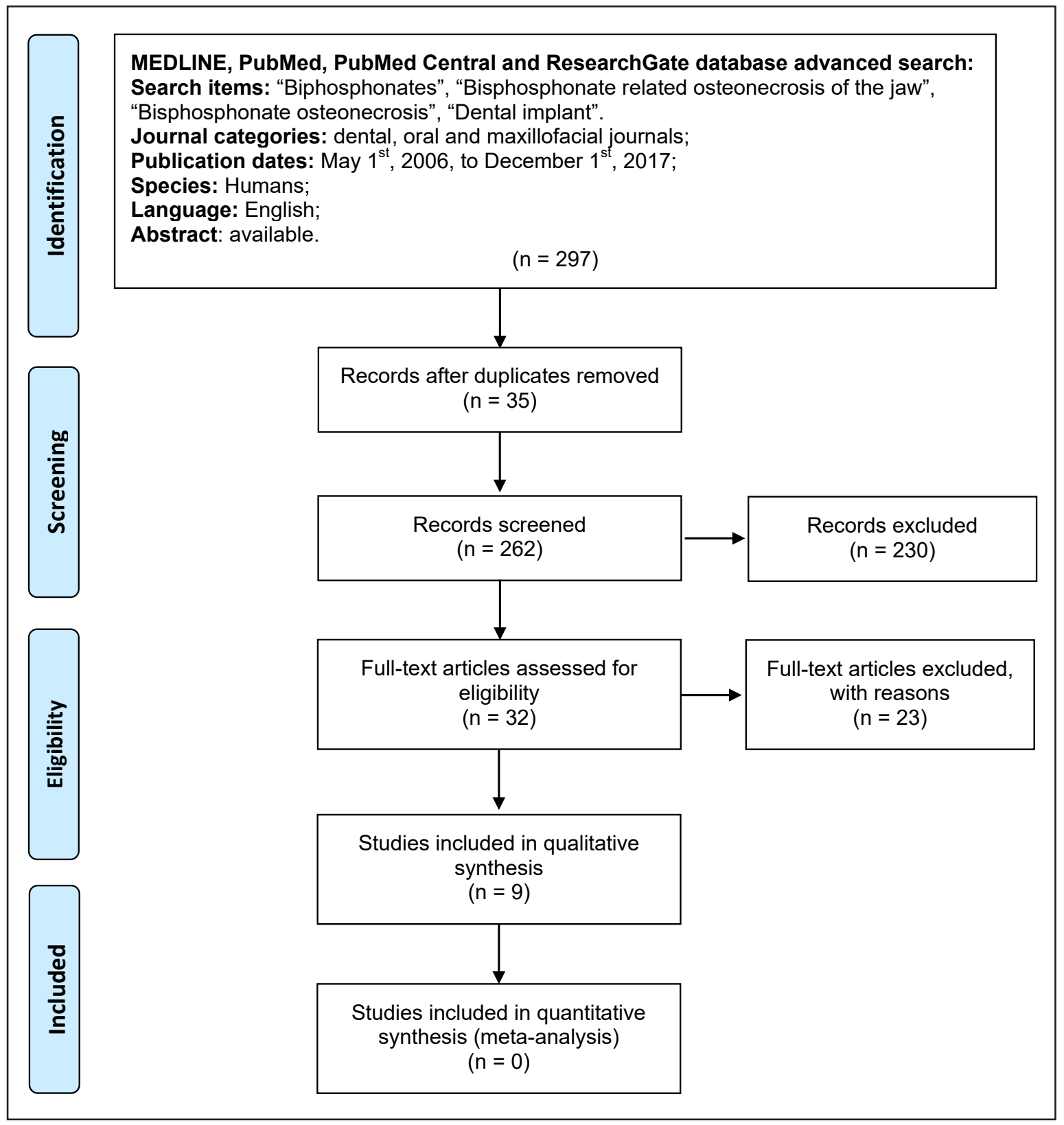

Figure 1. Flow diagram of studies selection according PRISMA guidelines.

- "Implant survival rate in control group" - success rate of implants during follow-ups among the patients without a history of BP therapy.

- "Implant survival rate in study group" - success rate of implants during follow-ups among the patients on BP therapy.

- "Mean age of follow-up" - medium time interval of follow-ups for patients after implant placement.

- "Year" - reveals the year of publication.

\section{Assessment of methodological quality}

The quality of all included studies was assessed during the data extraction process. The Cochrane Collaboration's two-part tool for assessing risk of bias [6] was used to assess bias across the studies and identify papers with intrinsic methodological and design flaws (Table 3). The Cochrane risk of bias tool was used for randomized clinical trial assessment, and appraisal checklist tool [7] was used for case reports (Table 4). Nonrandomized studies were not found during the literature search.

\section{Synthesis of results}

Relevant data of interest on the previously stated variables were collected and organized into Table 5 .

\section{Statistical analysis}

No meta-analysis could be performed due to the heterogeneity between the studies. 
Table 3. Quality assessment for randomized clinical trials (Cochrane risk of bias tool) [] $]$

\begin{tabular}{|c|c|c|c|c|c|c|c|c|}
\hline Study & $\begin{array}{c}\text { Year of } \\
\text { publication }\end{array}$ & $\begin{array}{c}\text { Random } \\
\text { sequence } \\
\text { generation } \\
\end{array}$ & $\begin{array}{l}\text { Allocation } \\
\text { concealment }\end{array}$ & $\begin{array}{c}\text { Blinding of } \\
\text { participants } \\
\text { and personnel }\end{array}$ & $\begin{array}{l}\text { Blinding of } \\
\text { outcome } \\
\text { assessment }\end{array}$ & $\begin{array}{c}\text { Incomplete } \\
\text { outcome } \\
\text { data }\end{array}$ & $\begin{array}{l}\text { Selective } \\
\text { reporting }\end{array}$ & $\begin{array}{l}\text { Other } \\
\text { bias }\end{array}$ \\
\hline Siebert et al. [33] & 2015 & High & High & Low & High & Low & Low & Low \\
\hline Lazarovici et al. [34] & 2010 & High & High & Unclear & High & Low & Low & Low \\
\hline Shabestari et al. [36] & 2010 & High & High & Unclear & High & Low & Low & High \\
\hline Bell and Bell [37] & 2008 & High & High & Unclear & High & Low & Low & Low \\
\hline Fugazzotto et al. [38] & 2007 & High & High & Unclear & High & Low & Low & High \\
\hline Jeffcoat [39] & 2006 & High & Low & Low & High & Low & Low & Low \\
\hline
\end{tabular}

Table 4. Quality assessment for case reports (the Joanna Briggs Institute appraisal checklist tool) []]

\begin{tabular}{l|c|c|c}
\hline \multicolumn{1}{c|}{ Appraisal checklist } & \multicolumn{3}{c}{ Study } \\
\cline { 2 - 4 } & $\begin{array}{c}\text { Rugani et al. } \\
2015[31]\end{array}$ & $\begin{array}{c}\text { Sverzut et al. } \\
2012[32]\end{array}$ & $\begin{array}{c}\text { Torres et al. } \\
2009[35]\end{array}$ \\
\hline Were patient's demographic characteristics clearly described? & Yes & Yes & Yes \\
\hline Was the patient's history clearly described and presented as a timeline? & Yes & Yes & Yes \\
\hline Was the current clinical condition of the patient on presentation clearly described? & Yes & Yes & Yes \\
\hline Were diagnostic tests or assessment methods and the results clearly described? & Yes & Yes & Yes \\
\hline Was the intervention(s) or treatment procedure(s) clearly described? & Yes & Yes & Yes \\
\hline Was the post-intervention clinical condition clearly described? & Yes & Yes & Yes \\
\hline Were adverse events (harms) or unanticipated events identified and described? & $\begin{array}{c}\text { Not } \\
\text { applicable }\end{array}$ & Yes & Not \\
& Yes & Yes & Yes \\
\hline Does the case report provide takeaway lessons? & Include & Include & Include \\
\hline Overall appraisal: [Yes/No/Unclear/Not applicable] & &
\end{tabular}

Table 5. Implant survival rate among the studies

\begin{tabular}{|c|c|c|c|c|c|c|c|c|}
\hline Study & Type of drug & $\begin{array}{l}\text { Reason of } \\
\text { medication }\end{array}$ & $\begin{array}{l}\text { Mean age of } \\
\text { medication use } \\
\quad \text { (months) }\end{array}$ & $\begin{array}{c}\text { Implants } \\
\text { in control } \\
\text { group }\end{array}$ & $\begin{array}{c}\text { Implants } \\
\text { in study } \\
\text { group }\end{array}$ & \begin{tabular}{|c|} 
Implant \\
survival rate \\
in control \\
group \\
\end{tabular} & $\begin{array}{c}\text { Implant } \\
\text { survival rate } \\
\text { in study } \\
\text { group }\end{array}$ & $\begin{array}{c}\text { Mean age of } \\
\text { follow-up } \\
\text { (months) }\end{array}$ \\
\hline Rugani et al. [31] & $\begin{array}{c}\text { Iv BP } \\
\text { (ibandronate) }\end{array}$ & Osteoporosis & 12 & - & 2 & - & $100 \%$ & 16 \\
\hline Sverzut et al. [32] & $\begin{array}{c}\text { Iv BP } \\
\text { (zoledronic acid) }\end{array}$ & Breast cancer & 72 & - & $3+3$ & - & $0 \%$ & $18+6$ \\
\hline Siebert et al. [33] & $\begin{array}{c}\text { Iv BP } \\
\text { (zoledronic acid) }\end{array}$ & Osteoporosis & 30 & 60 & 60 & $100 \%$ & $100 \%$ & 12 \\
\hline \multirow[b]{2}{*}{$\begin{array}{l}\text { Lazarovici }^{\mathrm{a}} \text { et al. } \\
\text { [34] }\end{array}$} & $\begin{array}{c}\text { Oral BP } \\
\text { (alendronate) }\end{array}$ & \multirow{2}{*}{$\begin{array}{c}\text { Osteoporosis } \\
\text { breast, prostate } \\
\text { cancer, multiple } \\
\text { myeloma }\end{array}$} & 68 & \multirow[b]{2}{*}{ - } & $\begin{array}{c}11 \\
\text { patients }\end{array}$ & \multirow[b]{2}{*}{-} & $\begin{array}{c}7 \text { patients } \\
(63 \%)\end{array}$ & \multirow[b]{2}{*}{11.4} \\
\hline & $\begin{array}{c}\text { Iv BP } \\
\text { (zoledronic acid/ } \\
\text { pamidronate) }\end{array}$ & & 68 & & $\begin{array}{c}16 \\
\text { patients }\end{array}$ & & $\begin{array}{l}5 \text { patients } \\
(31 \%)\end{array}$ & \\
\hline Torres et al. [35] & $\begin{array}{c}\text { Oral BP } \\
\text { (Risedronate) }\end{array}$ & Paget's disease & 84 & - & 6 & - & $100 \%$ & 48 \\
\hline $\begin{array}{l}\text { Shabestari et al. } \\
{[36]}\end{array}$ & $\begin{array}{c}\text { Oral BP } \\
\text { (alendronate) }\end{array}$ & Osteoporosis & 20.5 & - & 46 & - & $100 \%$ & 51.6 \\
\hline Bell and Bell [37] & $\begin{array}{c}\text { Oral BP } \\
\text { (alendronate/ } \\
\text { risedronate/ } \\
\text { ibandronate) }\end{array}$ & Osteoporosis & From 6 to 132 & 734 & 100 & $96.5 \%$ & $95 \%$ & 37.2 \\
\hline $\begin{array}{l}\text { Fugazzotto et al. } \\
\text { [38] }\end{array}$ & $\begin{array}{c}\text { Oral BP } \\
\text { (alendronate/ } \\
\text { risedronate) }\end{array}$ & Osteoporosis & 39.6 & - & 169 & - & $100 \%$ & 18.2 \\
\hline Jeffcoat [39] & $\begin{array}{c}\text { Oral BP } \\
\text { (alendronate/ } \\
\text { risendronate) }\end{array}$ & Osteoporosis & 36 & 108 & 102 & $99.2 \%$ & $100 \%$ & 36 \\
\hline
\end{tabular}

${ }^{a}$ Lazarovici et al. [34] case concluded patients that already showed with implant-related BRONJ. Antibiotic therapy and canceling BP medication was the treatment strategy. And implant survival rate after the treatment was $63 \%$ (Intraorally medicated patients) and $31 \%$ (intravenously medicated patients).

$\mathrm{Iv}=$ intravenous; $\mathrm{BP}=$ bisphosphonates. 


\section{RESULTS}

\section{Study selection}

Article review and data extraction were performed according to the PRISMA flow diagram. The initial search identified a total of 297 articles (Figure 1). The inclusion and exclusion criteria were applied to the 32 full-text articles. Finally, 9 articles were included in the review.

\section{Exclusion of studies}

The reasons for excluding studies after full-text assessment were as follows: non-human studies $(\mathrm{n}=$ 5) [8-12], in vitro studies $(\mathrm{n}=2)$ [13-14], systematic reviews $(\mathrm{n}=16)$ [15-30].

\section{Risk of bias across studies}

Summarizing the risk of bias for each randomized clinical trial, no studies were classified as an unclear or low risk (of bias for one or more key domains); due to similar methodologies of the studies, all of them appeared to have a high risk (of bias for more than one domain) [31-39]. Siebert et al. [33] and Jeffcoat [39] presented most of the low-risk domains corresponding with 4 and 5 out of the 7 fields (Table 3). All the recapped case reports showed high appraisal with only 1 field (Were adverse events [harms] or unanticipated events identified and described?) in both Rugani et al. [31] and Torres et al. [35] appearing to be "Not applicable" (Table 4).

\section{Study characteristics}

Results were summed up (Table 5) using an evaluation of drug type, time interval of $\mathrm{BP}$ use, number of implants placed in study group with their success rate, success rate of implants placed in control group and interval of re-examinations.

\section{Intravenous medication outcomes}

Rugani et al. [31] published a successful case report in 2015. A patient with osteoporosis was treated with intravenous BPs for more than a year. Over the time, BRONJ was diagnosed, so the medication was suspended. Local inflammation treatment, removal of necrotic parts, surgical revision of the wound and wound closure was used to stop the inflammation. A 9-month follow-up confirmed better condition of soft tissue and regeneration of necrotic bone. After confirmation that no pathological or inflammatory elements occurred in the jaw, an implantation procedure was planned. Two implants were inserted in the first and second mandibular left molar space. The standard protocol for implantation was used, and no complications were observed at the healing stage. Sixteen months later no inflammatory signs in soft and bone tissues were observed. In 2012, Sverzut et al. [32] in a case report presented a female patient with a history of breast cancer treatment; radiotherapy and chemotherapy were finished in 1995. From 2003 to 2009 , the patient had to receive an intravenous infusion of BP therapy once a month. In 2004, she had an implantation procedure in the right posterior region of her mandible and due to the pathological mobility, all the implants had to be removed (3 implants were placed that time) after 1.5 years of prosthetic treatment on implants. Later on in 2008, the same oral surgeon performed an implantation procedure for the same patient in the left posterior region of the mandible. Three implants were inserted and 6 months later, the patient was addressed to her physician at the oral and maxillofacial surgery clinic to confirm implant-related BRONJ. Another study was published by Siebert et al. [33] in 2015 . Twenty four female patients were divided into 2 groups. Group A consisted of 12 participants receiving intravenous BPs from osteoporosis ranging from 2 to 3 years of medication usage; group B was a control group without osteoporosis or any medication usage. Both groups of partially edentulous patients had their poor-condition teeth removed, and implants were immediately inserted. All the patients received antibiotic therapy (Amoxiclave: 1g. twice a day) during the postoperative stage for 6 days. After the 1-year followup, the survival rate of implants was $100 \%$ for both groups.

Lazarovici et al. [34] published a case in 2010 with examination of 145 patients of whom 27 had implantrelated osteonecrosis of the jaw. Eleven patients used oral BPs, and the rest had their medication infused intravenously. Mean length of medication usage time before appearance of BRONJ symptoms was 68 months. All the participants with implant-related osteonecrosis had to start antibiotic therapy, and if no sign of improvement was seen after the long-term therapy, the implant had to be removed. Overall, 16 patients had their inflammated bone implants removed and continued the antibiotic treatment (doxicicline: $100-200 \mathrm{mg} /$ day) until the full recovery was seen. Implant removal was not necessary for the rest of the patients because significant recovery was seen in the malignant area. Clinical observations after treatment expanded from 3 to 43 months. 


\section{Intraoral medication outcomes}

Torres et al. [35] published the clinical case in 2009 . In 2003, a 64-year-old woman with long-term oral BP medication from polyostotic Paget's disease was examined for mouth rehabilitation treatment. Intraoral BPs had been used weekly since 1996 . The treatment plan was to do implant-supported fixed prosthesis in the posterior partially edentulous maxilla. Six implants were placed in the right and left posterior regions following a routine protocol. A 10-day antibiotic therapy was prescribed (amoxicillin: three 750 -mg tabs/day). No post-operative pathological soft tissue or bony lesions were seen, and 6 months after implant placement, they were loaded with bridges. The patient was followed-up for 4 years, and the implants were successfully functional, and no peri-implant inflammation or implant mobility was seen.

Another publication written by Shabestari et al. [36] in 2010 involved a 21-patient study. All patients were osteoporotic women of whom 14 started BP therapy after implantation and tissue healing, and 7 of them already used intraoral BPs before implantation. Every patient had additional supplementary vitamin D and Calcium. All implants had been placed using a transgingival unloaded healing protocol. No significant difference was seen between post- or pre-use of the oral BPs or type of prosthesis, and none of the participants suffered from implant-related BRONJ post-insertion of implants during 0 - to 36-month follow-ups.

A retrospective study in 2008 was published by Bell and Bell [37] and involved examination of 100 dental implants in 42 patients. Intraoral BPs were prescribed from 6 months to 11 years and were still successfully being used after the surgery. Thirty participants of the group also received not only dental implants but also bone grafts, including 41 socket grafts, 10 sinus lifts, 13 guided tissue regenerations, 1 tunnel graft and 3 buccal contour regenerations. The mean duration of follow-up was 3.1 years (the shortest was 3 months, and the longest was 7.5 years) to ensure that no bone loss or inflammation occurred. Five implants failed, resulting in a $95 \%$ success rate $(96.5 \%$ success rate in 734 implants inserted by the same operator in the same year in patients without any history of BPs); although, oral BPs did not seem to be the reason for implant failure.

Fugazzotto et al. [38] presented a case of 61 patients, published in 2007. Participants of the case had a history of oral BP usage with a mean age of 3.3 years (interval from 1 to 5 years). One hundred sixty nine implants were placed, including 43 implants placed at the time of tooth removal. Range of followups were from 12 to 18 months and from 19 to 24 months respectively for 96 and 73 patients. All the participants showed no exposure of the bone or processes of inflammation that could confirm BRONJ, excluding 1 patient who was 1 -week post-operation and showed 2 - $3 \mathrm{~mm}$ exposed bone near the implant; although, the tissues were minimally debrided with a success of newly granulated soft tissue covering the exposed area.

Jeffcoat [39] published a controlled study on the alveolar bone taking effect from oral BPs in 2006. Twenty five postmenopausal women were using intraoral drugs for the mean age of 3 years. The control group of 25 age-matching participants were chosen with no history of BP therapy. One hundred two implants were placed in the BP-using participants versus 108 implants place in the control group subjects. Three years of examinations (radiographical and clinical diagnostics) with at least 1 visitation once a year showed a $100 \%$ success rate in the medicated group and a $99.2 \%$ success rate in the control group, resulting in no significant difference between groups. Overall, implant failure was considered if:

- Implant mobility appeared.

- Active inflammation for more than 8 weeks without healing with antibiotic therapy.

- Any sign of necrotic bone or unhealed soft tissues.

- Drainage of inflammatory matter near implant.

- Appearance of implant-related osteonecrosis of the jaw during follow-up.

\section{Outcome measures}

In conclusion, with outcomes put in (Table 5), only 14 patients were treated with intravenous medication and had 68 implants inserted. The interval of treatment by BPs was from 1 to 6 years. The average success rate of implant survival was $91 \%$ with 6 implants removed for one patient, who had 6 years of medication infusions intravenously, considering that other patients who showed success in implant stability were only medicated with intervals from 12 months to 2,5 years. Meanwhile, the control group was only studied in one research case with 12 patients and showed a $100 \%$ implant survival rate.

Patients with intraoral usage of medication showed better results with a sum of 150 patients who had 423 implants placed. The interval of intraoral medication use was from 6 months to 11 years. Showing no significant difference in the implant survival rate, which was $98.8 \%$ with only 5 implants out of 423 failed. The control groups from the 2 articles showed $97 \%$ success rate with only 27 implants failed out 
of 842. This gives us a better percentage of implant healing with intraoral BPs than with no medication usage in the control group and in the intravenously treated group, which was unreliable (considering that number of patients treated intravenously was too small). Lazarovici et al. [34] published a case series that was excluded out of the total results because the examined patients already had implantrelated BRONJ. Eleven patients used oral and 16 used intravenous BPs. Patients had to start long-term antibiotic therapy until full recovery and stabilization of the implants; if no difference was seen, the implants had to be removed. For 7 (63\%) patients using intraoral BPs, full recovery was seen without need to remove dental implants, and for intravenously treated patients, only $5(31 \%)$ recovered.

\section{DISCUSSION}

BPs have been commonly used for more than two decades. This type of medication helps millions of postmenopausal women stabilize the processes of osteoporosis; they are drugs of choice for malignant skeletal diseases to decrease resorption and pathological fractures of bone, and they benefit patients with hypercalcemia and Paget's disease. Although, some manipulations in the maxilla or mandible such as teeth extractions, periodontal surgeries, implantation procedures or other surgically invasive oral procedures on BPs was highly discussed and discouraged in lots of literature sources because of possible BRONJ occurrence. It is difficult to manage this type of osteonecrosis even though there have been numerous successful cases, treatment protocols and strategies presented in the time range from the first BRONJ that was published by Marx [40] in 2003. The basis of BP-induced osteonecrosis staging has not changed in the time (Table 1), although moderations of treatment were found and tested. With advanced healing strategies and experience with BPs, there is a possibility to increase the patient's quality of life fully, meaning that full or partial mouth rehabilitation may be considered with dental implant placement. Reviews of case studies have shown that with the right planning (radiographic evaluations, reduction of unhealthy habits), examination of patients (type of disease, time of medication use, type of BPs, anamnesis) and good inspection of clinical evidence (oral hygiene, removal of improper prosthesis or dental restorations), it is possible to use dental implants even in patients on BP therapy. Although, risk factors should be evaluated because for patients with intravenous infusions of BPs, BRONJ may appear 7 times more likely than medication used orally [41]. Ruggiero et. al [42] suggests that implant placement should be avoided in patients who are on intravenous bisphosphonate therapy or treated from cancer.

Results showed no significant implant success rate difference in intravenously and orally medicated groups, but only 3 case studies [31-33] with intravenous BPs were revised, which makes this study group statistically unreliable. On the other hand, intraoral BPs should be considered safe, assuming that only 5 out of 423 studied implants failed; although, Bell and Bell [37] mentioned that therapy of BPs did not seem to be a reason for the failed implants. American Association of Oral and Maxillofacial Surgeons [43], affirmed that using intraoral BPs more than 3 years gets patients to a higher risk of BRONJ appearance if oral surgical manipulations are done, although 3 cases studied patients with history of more than 3 years of intraoral drug consumption with high success of implantation procedures with only 5 implants failed out of $275[\underline{35}, \underline{37}, \underline{38}]$. Treatment with implants can be considered safe with intraoral BPs; although, good preparation of patient pre-operatively (professional oral hygiene, drug holidays if needed, prescription of antibacterial mouth rinses) and proper time of medications (antibiotic therapy) and followups (at least 12 months of re-evaluations) have to be done for success. However, dental implants on intravenously treated patients should be studied more and are considerably unreliable. On the other hand, there are a number of articles that offer successful BRONJ treatment combinations; some approaches could benefit primary wound closure on dental implant placement. For example, platelet-rich plasma showed high improvement of primary wound closure and healing factors in Bocanegra-Pérez et al. [44], and Curi et al. [45] presented cases, compared with patients treated without thrombocyte concentrates [46-48]. Even better improvement outcomes were seen with PRF (platelet-rich fibrin) with studies carried out by Dincă et al. [49] and Kim et al. [무] with significantly better recovery and less delayed healing signs. Studies carried out by Mozzati $[51,52]$ showed that treatment with PRGF (plasma rich in growth factors) showed the best after-effects with no complications or recurrences during the follow-up. Preventive and diagnostic strategies are important in avoiding implant-related BRONJ, according to Marx et al. [53] and Kunchur et al. [54], CTX values of $150 \mathrm{pg} / \mathrm{mL}$ and more greatly reduced the risk of osteonecrosis occurrence. Speaking on preventive strategies, Tardast et al. [55] also discovered that patients who already developed BRONJ and were on 
corticosteroid therapy had lower rates of healing than patients who didn't use corticosteroids. Post-operative care is important, as mentioned in an article published by Freiberger et al. [56] that indicated that hyperbaric oxygen therapies benefit patients with a higher tissue healing rate. In conclusion, planning of implantation procedures with good post- and pre-operative methods is as important as implantation protocol alone. Superior satisfying results could be achieved with more complex treatment methods.

\section{CONCLUSIONS}

Few articles regarding patients treated with intravenous bisphosphonates and implant placement were found among the studied publications, meaning there is not enough evidence to ensure that implantation on these patients could be considered safe. Most of the studies investigated in this article showed high risk during the assessment of bias. More randomised trials with control groups are needed for statistically reliable results, meaning that precautions should be taken when assessing the final results.

Patients treated intravenously could have a higher chance of developing implant-related bisphosphonates-related osteonecrosis of the jaw. Intraoral bisphosphonates can be considered safe, if good pre- and post-operative care of the patient is in place. The mean age of medication taken for intraoral bisphosphonates does not seem to have any influence on the implant survival rate or the development of bisphosphonates-related osteonecrosis. Meanwhile, it is unreasonable to affirm that intravenous medication usage time can have an effect on implant-related bisphosphonates-related osteonecrosis due to the lack of patients and implants placed in the investigated group.

\section{ACKNOWLEDGMENTS AND DISCLOSURE STATEMENTS}

The authors declare that there are no financial or other conflicts of interest related to this publication.

\section{REFERENCES}

1. IMS Health. National Prescription Audit (NPA) Plus ${ }^{\mathrm{TM}}$ database. May 2006. [URL: https://www.iqvia.com/]

2. Wysowski DK, Greene P. Trends in osteoporosis treatment with oral and intravenous bisphosphonates in the United States, 2002-2012. Bone. 2013 Dec;57(2):423-8. [Medline: 24063946] [doi: 10.1016/j.bone.2013.09.008]

3. Badros A, Weikel D, Salama A, Goloubeva O, Schneider A, Rapoport A, Fenton R, Gahres N, Sausville E, Ord R, Meiller T. Osteonecrosis of the jaw in multiple myeloma patients: clinical features and risk factors. J Clin Oncol. 2006 Feb 20;24(6):945-52. [Medline: 16484704] [doi: 10.1200/JCO.2005.04.2465]

4. Mellado-Valero A, Ferrer-García JC, Calvo-Catalá J, Labaig-Rueda C. Implant treatment in patients with osteoporosis. Med Oral Patol Oral Cir Bucal. 2010 Jan 1;15(1):e52-7. [Medline: 19767691] [doi: 10.4317/medoral.15.e52]

5. Moher D, Liberati A, Tetzlaff J, Altman DG; PRISMA Group. Preferred reporting items for systematic reviews and meta-analyses: the PRISMA statement. PLoS Med. 2009 Jul 21;6(7):e1000097. [Medline: 19621072] [PMC free article: 2707599] [doi: 10.1371/journal.pmed.1000097]

6. Higgins JPT, Green S. Cochrane Handbook for Systematic Reviews of Interventions. Version 5.1.0 [updated March 2011]. The Cochrane Collaboration, 2011. [URL: www.handbook.cochrane.org]

7. Joanna Briggs Institute Reviewer's Manual. Aromataris E, Munn Z, editors. The Joanna Briggs Institute. 2017. [URL: https://reviewersmanual.joannabriggs.org/]

8. Dikicier E, Karaçaylı Ü, Dikicier S, Günaydın Y. Effect of systemic administered zoledronic acid on osseointegration of a titanium implant in ovariectomized rats. J Craniomaxillofac Surg. 2014 Oct;42(7):1106-11. [Medline: 24530079] [doi: 10.1016/j.jcms.2014.01.039]

9. Kim I, Ki H, Lee W, Kim H, Park JB. The effect of systemically administered bisphosphonates on bony healing after tooth extraction and osseointegration of dental implants in the rabbit maxilla. Int J Oral Maxillofac Implants. 2013 Sep-Oct;28(5):1194-200. [Medline: 24066308] [doi: 10.11607/jomi.2685]

10. Kwon DH, Lee SJ, Wikesjö UME, Johansson PH, Johansson CB, Sul YT. Bone tissue response following local drug delivery of bisphosphonate through titanium oxide nanotube implants in a rabbit model. J Clin Periodontol. 2017 Sep;44(9):941-949. [Medline: 28703333] [doi: 10.1111/jcpe.12776]

11. Li JP, Li P, Hu J, Dong W, Liao NN, Qi MC, Li JY. Early healing of hydroxyapatite-coated implants in grafted bone of zoledronic acid-treated osteoporotic rabbits. J Periodontol. 2014 Feb;85(2):308-16. [Medline: 23688100] [doi: 10.1902/jop.2013.130046]

12. Oh KC, Hwang W, Park YB, Lee JH, Moon HS, Kim JH. Effects of Alendronate on Bone Remodeling Around Osseointegrated Implants in Rats. Implant Dent. 2017 Feb;26(1):46-53. [Medline: 27779611] [doi: 10.1097/ID.0000000000000497] 
13. Alqhtani NR, Logan NJ, Meghji S, Leeson R, Brett PM. Low dose effect of bisphosphonates on hMSCs osteogenic response to titanium surface in vitro. Bone Rep. 2017 Feb 16;6:64-69. [Medline: 28377984] [PMC free article: 5365309] [doi: 10.1016/j.bonr.2017.02.002]

14. Kim HS, Lee JI, Yang SS, Kim BS, Kim BC, Lee J. The effect of alendronate soaking and ultraviolet treatment on boneimplant interface. Clin Oral Implants Res. 2017 Sep;28(9):1164-1172.. [Medline: 27458172] [doi: 10.1111/clr.12933]

15. Alenezi A, Chrcanovic B, Wennerberg A. Effects of Local Drug and Chemical Compound Delivery on Bone Regeneration Around Dental Implants in Animal Models: A Systematic Review and Meta-Analysis. Int J Oral Maxillofac Implants. 2018 Jan/Feb;33(1):e1-e18. [Medline: 29340346] [doi: 10.11607/jomi.6333]

16. Ata-Ali J, Ata-Ali F, Peñarrocha-Oltra D, Galindo-Moreno P. What is the impact of bisphosphonate therapy upon dental implant survival? A systematic review and meta-analysis. Clin Oral Implants Res. 2016 Feb;27(2):e38-46. [Medline: 25406770] [doi: 10.1111/clr.12526]

17. Bedogni A, Bettini G, Totola A, Saia G, Nocini PF. Oral bisphosphonate-associated osteonecrosis of the jaw after implant surgery: a case report and literature review. J Oral Maxillofac Surg. 2010 Jul;68(7):1662-6. [Medline: 20561470] [doi: $10.1016 /$ j.joms.2010.02.037]

18. Boquete-Castro A, Gómez-Moreno G, Calvo-Guirado JL, Aguilar-Salvatierra A, Delgado-Ruiz RA. Denosumab and osteonecrosis of the jaw. A systematic analysis of events reported in clinical trials. Clin Oral Implants Res. 2016 Mar;27(3):367-75. [Medline: 25639776] [doi: 10.1111/clr.12556]

19. Chadha GK, Ahmadieh A, Kumar S, Sedghizadeh PP. Osseointegration of dental implants and osteonecrosis of the jaw in patients treated with bisphosphonate therapy: a systematic review. J Oral Implantol. 2013 Aug;39(4):510-20. [Medline: 23964780] [doi: 10.1563/AAID-JOI-D-11-00234]

20. de-Freitas NR, Lima LB, de-Moura MB, Veloso-Guedes CC, Simamoto-Júnior PC, de-Magalhães D. Bisphosphonate treatment and dental implants: A systematic review. Med Oral Patol Oral Cir Bucal. 2016 Sep 1;21(5):e644-51. [Medline: 27475681] [PMC free article: 5005105]

21. Guazzo R, Sbricoli L, Ricci S, Bressan E, Piattelli A, Iaculli F. Medication-related osteonecrosis of the jaw and dental implants failures: a systematic review. J Oral Implantol. 2016 Oct 4. [Medline: 27700557] [doi: 10.1563/aaid-joi-D-16-00057]

22. Zahid TM, Wang BY, Cohen RE. Influence of bisphosphonates on alveolar bone loss around osseointegrated implants. J Oral Implantol. 2011 Jun;37(3):335-46. [Medline: 20594057] [doi: 10.1563/AAID-JOI-D-09-00114]

23. Guimarães MB, Antes TH, Dolacio MB, Pereira DD, Marquezan M. Does local delivery of bisphosphonates influence the osseointegration of titanium implants? A systematic review. Int J Oral Maxillofac Surg. 2017 Nov;46(11):1429-1436. [Medline: 28521963] [doi: 10.1016/j.ijom.2017.04.014]

24. Kalra S, Jain V. Dental complications and management of patients on bisphosphonate therapy: A review article. J Oral Biol Craniofac Res. 2013 Jan-Apr;3(1):25-30. [Medline: 25737876] [PMC free article: 3942225] [doi: 10.1016/i.jobcr.2012.11.001]

25. Kellesarian SV, Abduljabbar T, Vohra F, Malignaggi VR, Malmstrom H, Romanos GE, Javed F. Role of local alendronate delivery on the osseointegration of implants: a systematic review and meta-analysis. Int J Oral Maxillofac Surg. 2017 Jul;46(7):912-921. [Medline: 28366449] [doi: 10.1016/j.ijom.2017.03.009]

26. Madrid C, Sanz M. What impact do systemically administrated bisphosphonates have on oral implant therapy? A systematic review. Clin Oral Implants Res. 2009 Sep;20 Suppl 4:87-95. [Medline: 19663954] [doi: $10.1111 / j .1600-0501.2009 .01772 . x$ ]

27. Montoya-Carralero JM, Parra-Mino P, Ramírez-Fernández P, Morata-Murcia IM, Mompeán-Gambín Mdel C, CalvoGuirado JL. Dental implants in patients treated with oral bisphosphonates: a bibliographic review. Med Oral Patol Oral Cir Bucal. 2010 Jan 1;15(1):e65-9. [Medline: 19767707] [doi: 10.4317/medoral.15.e65]

28. Qamheya AHA, Yeniyol S, Arisan V. Bisphosphonate-related osteonecrosis of the jaw and dental implants. J Istanb Univ Fac Dent. 2016 Jan 12;50(1):59-64. [Medline: 28955557] [PMC free article: 5573455] [doi: 10.17096/jiufd.24812]

29. Walter C, Al-Nawas B, Wolff T, Schiegnitz E, Grötz KA. Dental implants in patients treated with antiresorptive medication - a systematic literature review. Int J Implant Dent. 2016 Dec;2(1):9. [Medline: 27747701] [PMC free article: 5005701] [doi: 10.1186/s40729-016-0041-7]

30. Shin EY, Kwon YH, Herr Y, Shin SI, Chung JH. Implant failure associated with oral bisphosphonate-related osteonecrosis of the jaw. J Periodontal Implant Sci. 2010 Apr;40(2):90-5. [Medline: 20498766] [PMC free article: 2872811] [doi: $10.5051 /$ ipis.2010.40.2.90]

31. Rugani P, Kirnbauer B, Acham S, Truschnegg A, Jakse N. Implant Placement Adjacent to Successfully Treated Bisphosphonate-Related Osteonecrosis of the Jaw (BRONJ). J Oral Implantol. 2015 Jul;41 Spec No:377-81. [Medline: 24593250] [doi: 10.1563/AAID-JOI-D-13-00178]

32. Sverzut CE, Sverzut AT, de Matos FP, Kato RB, Trivellato AE, de Oliveira PT. Mandibular bisphosphonaterelated osteonecrosis after dental implant rehabilitation: a case report. Implant Dent. 2012 Dec;21(6):449-53. [Medline: 23075811] [doi: 10.1097/ID.0b013e3182703c4f]

33. Siebert T, Jurkovic R, Statelova D, Strecha J. Immediate Implant Placement in a Patient With Osteoporosis Undergoing Bisphosphonate Therapy: 1-Year Preliminary Prospective Study. J Oral Implantol. 2015 Jul;41 Spec No:360-5. [Medline: 24041299] [doi: 10.1563/AAID-JOI-D-13-00063] 
34. Lazarovici TS, Yahalom R, Taicher S, Schwartz-Arad D, Peleg O, Yarom N. Bisphosphonate-related osteonecrosis of the jaw associated with dental implants. J Oral Maxillofac Surg. 2010 Apr;68(4):790-6. [Medline: 20307764] [doi: 10.1016/j.joms.2009.09.017]

35. Torres J, Tamimi F, Garcia I, Herrero A, Rivera B, Sobrino JA, Hernández G. Dental implants in a patient with Paget disease under bisphosphonate treatment: a case report. Oral Surg Oral Med Oral Pathol Oral Radiol Endod. 2009 Mar;107(3):387-92. [Medline: 19217014] [doi: 10.1016/i.tripleo.2008.11.024]

36. Shabestari GO, Shayesteh YS, Khojasteh A, Alikhasi M, Moslemi N, Aminian A, Masaeli R, Eslami B, Treister NS. Implant placement in patients with oral bisphosphonate therapy: a case series. Clin Implant Dent Relat Res. 2010 Sep;12(3):175-80. [Medline: 19438964]

37. Bell BM, Bell RE. Oral bisphosphonates and dental implants: a retrospective study. J Oral Maxillofac Surg. 2008 May;66(5):1022-4. [Medline: 18423296] [doi: 10.1016/j.joms.2007.12.040]

38. Fugazzotto PA, Lightfoot WS, Jaffin R, Kumar A. Implant placement with or without simultaneous tooth extraction in patients taking oral bisphosphonates: postoperative healing, early follow-up, and the incidence of complications in two private practices. J Periodontol. 2007 Sep;78(9):1664-9. [Medline: 17760533] [doi: 10.1902/jop.2007.060514]

39. Jeffcoat MK. Safety of oral bisphosphonates: controlled studies on alveolar bone. Int J Oral Maxillofac Implants. 2006 May-Jun;21(3):349-53. [Medline: 16796276]

40. Marx RE. Pamidronate (Aredia) and zoledronate (Zometa) induced avascular necrosis of the jaws: a growing epidemic. J Oral Maxillofac Surg. 2003 Sep;61(9):1115-7. [Medline: 12966493] [doi: 10.1016/S0278-2391(03)00720-1]

41. López-Cedrún JL, Sanromán JF, García A, Peñarrocha M, Feijoo JF, Limeres J, Diz P. Oral bisphosphonate-related osteonecrosis of the jaws in dental implant patients: a case series. Br J Oral Maxillofac Surg. 2013 Dec;51(8):874-9. [Medline: 23866309] [doi: 10.1016/j.bjoms.2013.06.011]

42. Ruggiero SL, Dodson TB, Assael LA, Landesberg R, Marx RE, Mehrotra B; American Association of Oral and Maxillofacial Surgeons. American Association of Oral and Maxillofacial Surgeons position paper on bisphosphonaterelated osteonecrosis of the jaws--2009 update. J Oral Maxillofac Surg. 2009 May;67(5 Suppl):2-12. [Medline: 19371809] [doi: 10.1016/j.joms.2009.01.009]

43. Advisory Task Force on Bisphosphonate-Related Ostenonecrosis of the Jaws, American Association of Oral and Maxillofacial Surgeons. American Association of Oral and Maxillofacial Surgeons position paper on bisphosphonaterelated osteonecrosis of the jaws. J Oral Maxillofac Surg. 2007 Mar;65(3):369-76. [Medline: 17307580] [doi: 10.1016/j.joms.2006.11.003]

44. Bocanegra-Pérez S, Vicente-Barrero M, Knezevic M, Castellano-Navarro JM, Rodríguez-Bocanegra E, RodríguezMillares J, Pérez-Plasencia D, Ramos-Macías A. Use of platelet-rich plasma in the treatment of bisphosphonaterelated osteonecrosis of the jaw. Int J Oral Maxillofac Surg. 2012 Nov;41(11):1410-5. [Medline: 22647765] [doi: 10.1016/j.ijom.2012.04.020]

45. Curi MM, Cossolin GS, Koga DH, Zardetto C, Christianini S, Feher O, Cardoso CL, dos Santos MO. Bisphosphonaterelated osteonecrosis of the jaws--an initial case series report of treatment combining partial bone resection and autologous platelet-rich plasma. J Oral Maxillofac Surg. 2011 Sep;69(9):2465-72. [Medline: 21763050] [doi: 10.1016/j.joms.2011.02.078]

46. Nisi M, La Ferla F, Karapetsa D, Gennai S, Ramaglia L, Graziani F, Gabriele M. Conservative surgical management of patients with bisphosphonate-related osteonecrosis of the jaws: a series of 120 patients. Br J Oral Maxillofac Surg. 2016 Oct;54(8):930-935. [Medline: 27418080] [doi: 10.1016/j.bjoms.2016.06.015]

47. Scoletta M, Arduino PG, Dalmasso P, Broccoletti R, Mozzati M. Treatment outcomes in patients with bisphosphonaterelated osteonecrosis of the jaws: a prospective study. Oral Surg Oral Med Oral Pathol Oral Radiol Endod. $2010 \mathrm{Jul} ; 110(1): 46-53$. [Medline: 20452252] [doi: 10.1016/j.tripleo.2010.02.020]

48. Stockmann P, Vairaktaris E, Wehrhan F, Seiss M, Schwarz S, Spriewald B, Neukam FW, Nkenke E. Osteotomy and primary wound closure in bisphosphonate-associated osteonecrosis of the jaw: a prospective clinical study with 12 months follow-up. Support Care Cancer. 2010 Apr;18(4):449-60. [Medline: 19609572] [doi: 10.1007/s00520-009-0688-1]

49. Dincă O, Zurac S, Stăniceanu F, Bucur MB, Bodnar DC, Vlădan C, Bucur A. Clinical and histopathological studies using fibrin-rich plasma in the treatment of bisphosphonate-related osteonecrosis of the jaw. Rom J Morphol Embryol. 2014;55(3):961-4. [Medline: 25329128]

50. Kim JW, Kim SJ, Kim MR. Leucocyte-rich and platelet-rich fibrin for the treatment of bisphosphonate-related osteonecrosis of the jaw: a prospective feasibility study. Br J Oral Maxillofac Surg. 2014 Nov;52(9):854-9. [Medline: 25138613] [doi: 10.1016/j.bjoms.2014.07.256]

51. Mozzati M, Gallesio G, Pol R, Muzio G, Canuto R, Bergamasco L. A Report on a 7-year Follow up of the Surgical Management with PRGF $^{\circledR}$-ENDORET ${ }^{\circledR}$ of Oncologic Patients Affected by Intravenous Bisphosphonate Related Osteonecrosis of the Jaw. Surgery. 2013 May;S12:011. [doi: 10.4172/2161-1076.S12-011]

52. Mozzati M, Gallesio G, Arata V, Pol R, Scoletta M. Platelet-rich therapies in the treatment of intravenous bisphosphonaterelated osteonecrosis of the jaw: a report of 32 cases. Oral Oncol. 2012 May;48(5):469-74. [Medline: 22265335] [doi: 10.1016/i.oraloncology.2011.12.004] 
53. Marx RE, Cillo JE Jr, Ulloa JJ. Oral bisphosphonate-induced osteonecrosis: risk factors, prediction of risk using serum CTX testing, prevention, and treatment. J Oral Maxillofac Surg. 2007 Dec;65(12):2397-410. [Medline: 18022461] [doi: 10.1016/j.joms.2007.08.003]

54. Kunchur R, Need A, Hughes T, Goss A. Clinical investigation of C-terminal cross-linking telopeptide test in prevention and management of bisphosphonate-associated osteonecrosis of the jaws. J Oral Maxillofac Surg. 2009 Jun;67(6): 1167-73. [Medline: 19446200] [doi: 10.1016/j.joms.2009.02.004]

55. Tardast A, Sjöman R, Løes S, Abtahi J. Bisphosphonate associated osteomyelitis of the jaw in patients with bony exposure: prevention, a new way of thinking. J Appl Oral Sci. 2015 May-Jun;23(3):310-4. [Medline: 26221926] [PMC free article: $\underline{4510666]}$ [doi: 10.1590/1678-775720140506]

56. Freiberger JJ, Padilla-Burgos R, McGraw T, Suliman HB, Kraft KH, Stolp BW, Moon RE, Piantadosi CA. What is the role of hyperbaric oxygen in the management of bisphosphonate-related osteonecrosis of the jaw: a randomized controlled trial of hyperbaric oxygen as an adjunct to surgery and antibiotics. J Oral Maxillofac Surg. 2012 Jul;70(7):1573-83. [Medline: 22698292] [doi: 10.1016/j.joms.2012.04.001]

\section{To cite this article:}

Gelazius R, Poskevicius L, Sakavicius D, Grimuta V, Juodzbalys G.

Dental Implant Placement in Patients on Bisphosphonate Therapy: a Systematic Review

J Oral Maxillofac Res 2018;9(3):e2

URL: http://www.ejomr.org/JOMR/archives/2018/3/e2/v9n3e2.pdf

doi: $10.5037 /$ jomr.2018.9302

Copyright (C) Gelazius R, Poskevicius L, Sakavicius D, Grimuta V, Juodzbalys G. Published in the JOURNAL OF ORAL \& MAXILLOFACIAL RESEARCH (http://www.ejomr.org), 30 September 2018.

This is an open-access article, first published in the JOURNAL OF ORAL \& MAXILLOFACIAL RESEARCH, distributed under the terms of the Creative Commons Attribution-Noncommercial-No Derivative Works 3.0 Unported License, which permits unrestricted non-commercial use, distribution, and reproduction in any medium, provided the original work and is properly cited. The copyright, license information and link to the original publication on (http://www.ejomr.org) must be included. 